\title{
Apresentação:
}

\section{Imagens e palavras}

O número $7 \mathrm{da}$ revista de literatura Outra Travessia presta homenagem a Glauber Rocha, cineasta, escritor e pensador, discutindo não apenas sua obra (hoje disponível em DVD), mas também o acervo da Fundação Tempo Glauber, no Rio de Janeiro, empenhada em recuperar toda a filmografia do cineasta e manter em circulação seus textos poéticos e teóricos, como explica Paloma Rocha, em entrevista dada a Rosana Kamita. Na seqüência, o cineasta Joel Pizzini conversa com Dirce Waltrick do Amarante sobre o legado do Cinema Novo e esclarece o trabalho de pesquisa de Lúcia Rocha, mãe do artista baiano, a quem coube a iniciativa de reunir, ao longo de três décadas, o acervo hoje disponível aos pesquisadores, na Fundação Tempo Glauber. Fechando essa primeira seção da revista, o ensaísta Jair Tadeu da Fonseca analisa a linguagem neobarroca dos textos literários de Glauber Rocha, acompanhando-o numa "viagem lisérgica pelo sertão".

$\mathrm{Na}$ segunda seção da revista, três ensaios inter-relacionam o cinema com as outras artes, aprofundado a compressão da imagem, da palavra e da performance na atualidade. 0 primeiro ensaio, de Adalberto Muller, analisa as relações entre estudos literários e estudos de mídia, propondo o conceito de intermidialidade. $O$ segundo ensaio, de Eduardo Subirats, discute o nexo entre tortura e racionalidade civilizadora, recorrendo à literatura de Sade e ao cinema de Pasolini para desenvolver seus argumentos. No terceiro ensaio, Alai Garcia Diniz discute as relações entre romance e roteiro, tomando como referência a obra de Roa Bastos e a cultura oral latino-americana.

Se Glauber nos ensinou que poética e política são inseparáveis, Lacoue-Labarthe nos mostrou como ler a política do poema, elegendo os textos estéticos de Heidegger como objeto. Em dois depoimentos, escritos originalmente em francês, dois ex-alunos brasileiros do filósofo francês, morto em 2007, respectivamente João Camillo Pena e Virgínia de Araújo Figueiredo, discorrem sobre literatura, filosofia e política, relembrando o ensino de Lacoue-Labarthe. 
Na seção seguinte, Christophe Bident, biógrafo de Maurice Blanchot, analisa longamente a obra do autor de $O$ Espaço Literário e lembra que, para Blanchot, a leitura era "uma dança com um parceiro invisível, uma dança alegre, desvairada". Completa esse ensaio uma discussão, na forma de "conversa infinita", sobre a escrita, o desastre e o fragmento, que elucida diferentes facetas dos textos e do pensamento de Blanchot..

A revista Outra Travessia, neste número, também discute exaustivamente a origem e o sentido do termo intelligentsia, o papel do delírio na arte e a crise da ironia na pós-modernidade, em três ensaios independentes, assinados respectivamente por Aurora Fornoni Bernardini, Maria Esther Maciel e Caetano Waldrigues Galindo.

Finalmente, na última seção da revista, o romantismo alemão é abordado de perspectivas diferentes, em dois ensaios: no primeiro, de Karin Volobuef, o leitor é introduzido no romance inacabado de Novalis, que contraria as teses de Rousseau, e, no segundo, de Maria Aparecida Barbosa, o leitor acompanha o processo que transformou uma novela de Hoffmann, do século XIX, numa ópera moderna, do século XX. Assim, a revista Outra Travessia conclui como começou, discutindo conceito de intermidialidade na arte moderna e contemporânea, do Livro ao DVD e vice-versa.

No apêndice, o leitor poderá ler o roteiro de um vídeo sobre Glauber Rocha, de autoria de Silvia Biehl, no qual um personagem-cineasta, Rô, "desbocado e prepotente, não sabe por que quer copiar Glauber Rocha".

O editor 